\title{
The effect of the acetylator phenotype on the metabolism of sulphasalazine in man
}

\author{
A K AZAD KHAN, M NURAZZAMAN, AND S C TRUELOVE \\ From the Nuffield Department of Clinical Medicine and the Department of Haematology, Radcliffe \\ Infirmary, Oxford.
}

SUMMARY The metabolism of sulphasalazine (SASP) has been studied in three series of patients i with ulcerative colitis. In the first series, 185 patients were studied serially for 1 to 3 years while being maintained on treatment with $2 \mathrm{~g}$ SASP daily. This showed that the slow acetylators were $\dot{\omega}$ liable to have high serum concentrations of sulphapyridine (SP) whereas the concentrations of ? SASP and of 5-aminosalicylic acid (5-ASA) were not appreciably different in the fast and slow acetyla- tors. In the second series, 170 patients were admitted to a therapeutic trial designed to elicit the ${ }_{D}$ optimum dose of SASP for maintenance therapy. The patients were allotted at random to treatment $\frac{0}{2}$ with 1, 2, or $4 \mathrm{~g}$ daily for a period of 6 months. The bigger the dose of SASP the more effective was the treatment, but side effects were common with the bigger doses. The common symptomatic side effects of nausea, malaise, and headache were associated with high circulating levels of total SP and were $\varnothing_{\infty}$ almost always confined to the slow acetylators. Minor haematological effects were common and $\omega$ were dose related. With the exception of methaemoglobinaemia they were related to the circulating level of free SP and hence were more common among the slow acetylators. By contrast, methaemoglobinaemia was correlated with the circulating level of acetylated sulphapyridine and hence was $\overline{0}$ more common among the fast acetylators. In the third series, 36 patients on maintenance treatment $\frac{\varnothing}{\mathbb{Q}}$ with $2 \mathrm{~g}$ SASP daily were given prednisolone in a dose of $20 \mathrm{mg}$ daily for one week and dummy tablets for one week, these two treatments being applied in random order. The prednisolone had no음 appreciable effect on the serum concentration of SASP and its metabolites, but it increased the $\frac{3}{5}$ percentage acetylation to a small extent in both fast and slow acetylators.

Sulphasalazine is widely used in the treatment of ulcerative colitis and especially as long term maintenance treatment. ${ }^{12}$ Chemically it is salicyl-azosulphapyridine (SASP). When taken by mouth, only a small proportion of the drug is absorbed from the small intestine and most of the ingested dose reaches the colon intact. There the drug is split at the diazo bond by the colonic bacteria to yield sulphapyridine (SP) and 5-aminosalicylic acid (5-ASA). Virtually all the SP is absorbed from the colon and is then metabolised in the usual way of sulphonamides by $\mathrm{N}^{4}$-acetylation and ring hydroxylation. ${ }^{3-6}$ The hydroxylated compound undergoes glucuronidation and is present in the serum in this form.

The 5-ASA is only partly absorbed from the colon. About $25 \%$ is recoverable from the urine, about $50 \%$ is voided with the faeces, and the remainder cannot be accounted for.

The acetylation of SP has been shown to be Received for publication 6 May 1982. subject to genetic polymorphism and the general population can be divided into fast and slow 3 . acetylators. ${ }^{7}$ This has a bearing on the metabolism of the SP which is released from ingested SASP. ${ }^{8}$

The present study had three objectives. (1) Too determine the effect of the acetylator phenotype on? the metabolism of SASP. (2) To examine the re-o lationship between acetylator phenotype and the side effects of SASP therapy. (3) To obtain informa- $-\mathrm{r}$ tion about the possible effects of prednisolone on N the metabolism of SASP.

\section{Patients studied}

In a study designed to determine whether circulatinge levels of SASP and its metabolites influence thew clinical efficacy of the drug, 185 patients with ulcerative colitis being maintained on $2 \mathrm{~g}$ SASPO daily were examined serially over the course of 1 to 30 years. Repeated blood samples were taken and were्⿱ analysed for SASP and its metabolites. The clinicaf 
results have been presented separately. ${ }^{9}$ The present study deals with the influence of the acetylator phenotype on the circulating levels of SASP and its metabolites.

In a second study, 170 patients with ulcerative colitis volunteered to take part in a controlled therapeutic trial in which they were assigned at random to three treatment groups involving maintenance treatment with SASP at a dose of 1,2 , or $4 \mathrm{~g}$ daily for a trial period of 6 months. The main object of this study was to determine the optimum dose of SASP for maintenance treatment. The clinical results have been published elsewhere, ${ }^{10}$ but the study yielded information on the relationship between the acetylator phenotype and circulating levels of SASP and its metabolites with different doses of SASP, and also on the relationship between the acetylator phenotype and the liability to develop side effects of therapy. Both these topics will be dealt with in the present article.

In a third study, 36 patients with ulcerative colitis who were receiving 2 g SASP daily as maintenance treatment volunteered to take part in an investigation designed to show whether prednisolone influences the metabolism of SASP. The reason for making this study was that prednisolone is commonly administered in addition to SASP when a patient with ulcerative colitis suffers a relapse. The patients were assigned at random to treatment with prednisolone in a dose of $5 \mathrm{mg}$ four times a day or an equal number of dummy tablets. After one week, these two treatments were switched and were continued for a second week. Blood samples were obtained before entry into the trial and also at the end of the first and second weeks. These samples were analysed for SASP and its metabolites.

All the patients studied were white British subjects.

\section{Chemical methods}

SASP, SP, $\mathrm{N}^{4}$-acetyl-sulphapyridine (Ac-SP), sulphapyridine-O-glucuronide (SP-Gluc), $\mathrm{N}^{4}$-acetylsulphapyridine-O-glucuronide (Ac-SP-Gluc), and total 5-ASA (free 5-ASA + acetyl-5-ASA) were estimated in the serum by standard biochemical methods. ${ }^{11-13}$ Total sulphapyridine (total SP) represented the sum of freeSP and all the metabolites of SP.

The acetylator phenotype was determined from the ratio of free SP to total SP. ${ }^{7}$ The amount of SP in the acetylated form (Ac-SP+Ac-SP-Gluc) was determined and was expressed as a percentage of the total SP:

$$
\frac{(\text { Ac-SP })+(\text { Ac-SP-Gluc })}{\text { Total SP }} \times 100=\% \text { acetylation. }
$$

Similarly, the degree of hydroxylation was expressed as a percentage of total SP.

\section{Results}

EFFECT OF ACETYLATOR PHENOTYPE ON THE METABOLISM OF SASP

Table 1 shows the main results obtained in the first group, which consisted of 185 patients on maintenance therapy with $2 \mathrm{~g}$ SASP daily. Measurements of the serum concentrations were made in all of them on more than one occasion, the mean number of occasions being five. The acetylator phenotype was determined for 181 of the patients, the circulating levels of total SP being too low in the remaining four patients to provide reliable results. There was no overlap between the fast and slow acetylators in respect of percentage acetylation. The distribution of the acetylator phenotype was closely similar to that found by Evans ${ }^{7}$ for a sample of the general British population.

As far as SASP is concerned, the acetylator phenotype had no appreciable effect upon the serum concentrations. With respect to 5-ASA, the circulating levels were very low, usually being less than $1 \mu \mathrm{g} / \mathrm{ml}$ in 120 samples obtained from 50 of the patients. After this, no further estimations of 5-ASA were made, as these low serum concentrations meant that it was not feasible to determine the effect of the acetylator phenotype upon them.

By contrast, the acetylator phenotype had a major influence on the serum concentrations of SP and its metabolites. The average concentration of total SP was significantly higher in the slow acetylators but, as can be seen from the standard deviations, there was considerable overlap with the values found in the fast acetylators. In spite of this overlap, the patients with markedly high concentrations of total SP were chiefly found among the slow acetylators, as is plainly shown in table 2 .

Reverting to table 1 , it can be seen that the concentration of free SP was markedly higher in the slow acetylators while, conversely, the concentrations

TABLE 1 Serum concentrations of SASP and its SP metabolites in 181 patients with ulcerative colitis during remission shown separately for fast and slow acetylators. (The acetylator status could not be determined in four of the 185 patients studied.)

\begin{tabular}{|c|c|c|c|}
\hline & \multicolumn{3}{|c|}{ Serum concentrations $(\mu \mathrm{g} / \mathrm{ml})($ mean $\pm S D)$} \\
\hline & $\begin{array}{l}\text { Fast } \\
\text { acetylators } \\
(n=69)\end{array}$ & $\begin{array}{l}\text { Slow } \\
\text { acetylators } \\
(n=112)\end{array}$ & $t$ test \\
\hline \multirow{8}{*}{$\begin{array}{l}\text { SASP } \\
\text { Total SP } \\
\text { Free SP } \\
\text { AC-SP } \\
\text { SP-Gluc } \\
\text { AC-SP-Gluc } \\
\% \text { acetylation } \\
\% \text { hydroxyla- } \\
\text { tion }\end{array}$} & $6 \cdot 9 \pm 5 \cdot 4$ & $6 \cdot 1 \pm 3 \cdot 8$ & $t=1 \cdot 1 \mathrm{NS}$ \\
\hline & $20 \cdot 7 \pm 9 \cdot 6$ & $27 \cdot 0 \pm 10 \cdot 2$ & $t=3.7 \mathrm{p}<0.001$ \\
\hline & $7 \cdot 5 \pm 4 \cdot 3$ & $18 \cdot 5 \pm 8 \cdot 2$ & $t=9.2 \mathrm{p}<0.0001$ \\
\hline & $9 \cdot 7 \pm 4 \cdot 3$ & $5 \cdot 7 \pm 2 \cdot 4$ & $t=7.1 \mathrm{p}<0.0001$ \\
\hline & $0.4 \pm 0.4$ & $0.7 \pm 0.8$ & $t=2.0 \mathrm{p}<0.05$ \\
\hline & $3 \cdot 5 \pm 2 \cdot 0$ & $2 \cdot 3 \pm 1 \cdot 6$ & $t=4.1 \mathrm{p}<0.001$ \\
\hline & $63 \cdot 8 \pm 8 \cdot 6$ & $29 \cdot 7 \pm 7 \cdot 3$ & $t=25.5 \mathrm{p}<0.00001$ \\
\hline & $20 \cdot 2 \pm 9 \cdot 9$ & $11 \cdot 6 \pm 9 \cdot 6$ & $t=5.2 \mathrm{p}<0.001$ \\
\hline
\end{tabular}


TABLE 2 Distribution of patients with serum concentration of total SP of above $35 \mu \mathrm{g} / \mathrm{ml}$ in the fast and slow acetylators.

\begin{tabular}{|c|c|c|c|c|}
\hline \multirow[t]{2}{*}{$\begin{array}{l}\text { Acctylator } \\
\text { phenotype }\end{array}$} & \multirow[t]{2}{*}{$\begin{array}{l}\text { No of } \\
\text { patients }\end{array}$} & \multicolumn{2}{|c|}{$\begin{array}{l}\text { Patients with total } S P \\
\text { over } 35 \mu \mathrm{g} / \mathrm{ml} \text { of serum }\end{array}$} & \multirow[t]{2}{*}{$\begin{array}{l}\text { Significance } \\
\text { of difference }\end{array}$} \\
\hline & & $N o$ & $\%$ & \\
\hline $\begin{array}{l}\text { Fast } \\
\text { Slow }\end{array}$ & $\begin{array}{r}69 \\
112\end{array}$ & $\begin{array}{r}3 \\
20\end{array}$ & $\begin{array}{r}4 \cdot 3 \\
17 \cdot 9\end{array}$ & $\begin{array}{c}x^{2}=7.03 \\
\text { df }=1 \\
p<0.01\end{array}$ \\
\hline
\end{tabular}

of Ac-SP and Ac-SP-Gluc were higher in the fast acetylators.

The serum concentrations of SP-Gluc were somewhat higher in the slow acetylators than in the fast acetylators but the concentrations were low in both groups.

As far as hydroxylation is concerned, there are three points to be made. First, hydroxylation is a metabolic property which is unimodally distributed and varies greatly from one person to another, the degree of hydroxylation ranging from 1 to $75 \%$ in this series. Secondly, the serial observations made in the present study showed that hydroxylation varies appreciably in the same patient from time to time, in this respect differing from acetylation which remains relatively constant in any subject. For example, in one patient in whom this estimation was made on seven occasions the percentage hydroxylation was $15 \cdot 9,4 \cdot 7,33 \cdot 5,4 \cdot 1,9 \cdot 4,2 \cdot 4$, and 1.6 respectively, the mean value being 10.2 with a standard deviation of 11.4 . Thirdly, the percentage hydroxylation was almost twice as great in the fast acetylators as in the slow acetylators but this was almost certainly because of the fact that the concentration of total acetylated sulphapyridine was also almost twice as great in the fast acetylators. In other words, the difference in percentage hydroxylation represented only a difference in substrate concentrations and not in enzymatic activity as such.
RELATIONSHIP BETWEEN ACETYLATOR PHENOTYPE AND SIDE EFFECTS OF THERAPY.

In the second study, 170 patients with ulcerative colitis in remission were admitted to a controlled therapeutic trial in which they were assigned at random to three different dosages of $1 \mathrm{~g}, 2 \mathrm{~g}$, and $4 \mathrm{~g}$ SASP daily.

The acetylator phenotype was determined in 164 ळ of these patients, the serum concentrations of total $\overrightarrow{0}$ SP being too low in the remaining six patients for $\overrightarrow{\vec{H}}$ this determination to be made. There was no overlap $\vec{\omega}$ between the fast and slow acetylators in respect of the percentage acetylation.

Table 3 shows the serum concentrations of SASP i and its metabolites in the three dosage groups. It will be seen that the serum concentrations of SASP $\dot{\omega}$ and of total 5-ASA were not significantly different in the fast and slow acetylators at any of these dosages. By contrast, both free SP and total SP $\vec{T}$ concentrations were significantly greater in the slow acetylators at all dosage levels, and this difference became more pronounced with increasing doses.

As far as symptomatic side effects of the therapy were concerned, these were confined to the $4 \mathrm{~g}$ daily dosage group, not surprisingly as nearly all the patients were already on maintenance treatment with $2 \mathrm{~g}$ daily on entry to the trial. Out of 56 patients allotted to the $4 \mathrm{~g}$ daily dosage group, 21 developed side effects. Table 4 shows the mean serum concen- $\stackrel{2}{\circ}$ trations of SASP and its major metabolites in the $\stackrel{\mathbb{2}}{2}$ patients with and without side effects and also $\overrightarrow{\overrightarrow{0}}$ their acetylator phenotype. It can be seen that the 3 concentrations of SASP and of total 5-ASA were not appreciably different in the patients with side effects from those without side effects. On the other hand, the concentrations of both free SP and total SP were significantly higher in the patients with side effects. $\overline{0}$ Further analysis of the data shows that the association with side effects is chiefly related to free SP

TABLE 3 Serum concentration of SASP and its metabolites in fast and slow acetylators in the patients on different doses of SASP. The serum concentrations are expressed as $\mu \mathrm{g} / \mathrm{ml}$ and the values shown are the mean and the standard deviation. (The acetylator status could not be determined in six of the 170 patients studied.)

\begin{tabular}{|c|c|c|c|c|c|c|c|c|c|}
\hline \multirow{3}{*}{$\begin{array}{l}\text { Serum } \\
\text { concentration } \\
(\mu g / m l, \\
\text { mean } \pm S D)\end{array}$} & \multicolumn{9}{|c|}{ Dose of SASP } \\
\hline & \multicolumn{3}{|l|}{ I g daily } & \multicolumn{3}{|l|}{$2 \mathrm{~g}$ daily } & \multicolumn{3}{|l|}{$4 \mathrm{~g}$ daily } \\
\hline & $\begin{array}{l}\text { Fast } \\
\text { acetylator } \\
(n=19)\end{array}$ & $\begin{array}{l}\text { Slow } \\
\text { acetylator } \\
(n=33)\end{array}$ & t test & $\begin{array}{l}\text { Fast } \\
\text { acetylator } \\
(n=23)\end{array}$ & $\begin{array}{l}\text { Slow } \\
\text { acetylator } \\
(n=33)\end{array}$ & t test & $\begin{array}{l}\text { Fast } \\
\text { acetylator } \\
(n=2 I)\end{array}$ & $\begin{array}{l}\text { Slow } \\
\text { acetylator } \\
(n=35)\end{array}$ & t test \\
\hline SASP & $4 \cdot 5 \pm 2 \cdot 7$ & $7 \cdot 4 \pm 6 \cdot 9$ & $\begin{array}{c}t=1 \cdot 7 \\
\text { NS }\end{array}$ & $10 \cdot 0 \pm 10 \cdot 9$ & $6 \cdot 4 \pm 2 \cdot 6$ & $\begin{array}{c}t=1 \cdot 8 \\
\mathrm{NS}\end{array}$ & $16 \cdot 8 \pm 17 \cdot 2$ & $21 \cdot 1 \pm 16 \cdot 9$ & $\begin{array}{c}t=0.9 \\
\text { NS }\end{array}$ \\
\hline Free SP & $4 \cdot 7 \pm 1 \cdot 4$ & $11 \cdot 0 \pm 2 \cdot 3$ & $\begin{array}{l}t=10.1 \\
\mathrm{p}<0.0001\end{array}$ & $8 \cdot 6 \pm 3 \cdot 6$ & $18 \cdot 5 \pm 9 \cdot 0$ & $\begin{array}{l}t=4.7 \\
\mathrm{p}<0.001\end{array}$ & $14 \cdot 9 \pm 8 \cdot 5$ & $41 \cdot 2 \pm 14 \cdot 1$ & $\begin{aligned} t & =7.1 \\
\mathrm{p} & <0.0001\end{aligned}$ \\
\hline Total SP & $12 \cdot 1 \pm 3 \cdot 4$ & $15 \cdot 9 \pm 3 \cdot 4$ & $\begin{aligned} t & =3.7 \\
\mathrm{p} & <0.001\end{aligned}$ & $19 \cdot 4 \pm 7 \cdot 6$ & $27 \cdot 0 \pm 12 \cdot 7$ & $\begin{array}{c}t=2.5 \\
\mathrm{p}<0.02\end{array}$ & $35 \cdot 7 \pm 17 \cdot 3$ & $57 \cdot 9 \pm 18 \cdot 0$ & $\begin{array}{c}t=4.3 \\
\mathrm{p}<0.001\end{array}$ \\
\hline Total 5-ASA & $0 \cdot 7 \pm 0 \cdot 3$ & $0.7 \pm 0.7$ & $\begin{array}{c}t=0.5 \\
\text { NS }\end{array}$ & $1 \cdot 2 \pm 1 \cdot 8$ & $1 \cdot 1 \pm 0 \cdot 8$ & $\begin{array}{l}t=0.5 \\
\text { NS }\end{array}$ & $1 \cdot 3 \pm 0.7$ & $1 \cdot 9 \pm 1 \cdot 2$ & $\begin{array}{c}t=1.7 \\
\text { NS }\end{array}$ \\
\hline
\end{tabular}


TABLE 4 Serum concentrations of SASP and its metabolites and the acetylator phenotypes of patients ingesting $4 \mathrm{~g}$ SASP daily with or without clinical side effects.

\begin{tabular}{|c|c|c|c|c|c|c|c|c|}
\hline \multirow{2}{*}{$\begin{array}{l}\text { Symptomatic } \\
\text { side effects }\end{array}$} & \multirow{2}{*}{$\begin{array}{l}\text { No of } \\
\text { patients }\end{array}$} & \multicolumn{5}{|c|}{ Serum concentrations $(\mu \mathrm{g} / \mathrm{ml}$, mean $\pm S D)$} & \multicolumn{2}{|c|}{ Acetylator phenotype } \\
\hline & & $S A S P$ & Free $S P$ & Acetylated $S P$ & Total SP & Total 5-ASA & Fast & Slow \\
\hline $\begin{array}{l}\text { Present } \\
\text { Absent }\end{array}$ & $\begin{array}{l}21 \\
35\end{array}$ & $\begin{array}{l}22 \cdot 7 \pm 13 \cdot 8 \\
16 \cdot 0 \pm 15 \cdot 4\end{array}$ & $\begin{array}{l}37 \cdot 9 \pm 17 \cdot 1 \\
27 \cdot 6 \pm 17 \cdot 3\end{array}$ & $\begin{array}{l}21 \cdot 0 \pm 8 \cdot 1 \\
16 \cdot 1 \pm 8 \cdot 0\end{array}$ & $\begin{array}{l}57 \cdot 9 \pm 18 \cdot 6 \\
42 \cdot 9 \pm 20 \cdot 4\end{array}$ & $\begin{array}{l}2 \cdot 0 \pm 1 \cdot 3 \\
1 \cdot 5 \pm 0 \cdot 8\end{array}$ & $\begin{array}{r}5 \\
18\end{array}$ & $\begin{array}{l}16 \\
17\end{array}$ \\
\hline \multicolumn{2}{|c|}{ Statistical significance } & $\begin{array}{l}t=1 \cdot 4 \\
\text { NS }\end{array}$ & $\begin{array}{l}t=2.1 \\
\mathrm{p}<0.05\end{array}$ & $\begin{array}{l}t=1.9 \\
0.05<\mathrm{p}<0.1\end{array}$ & $\begin{array}{l}t=2.5 \\
\mathrm{p}<0.02\end{array}$ & $\begin{array}{l}t=1 \cdot 5 \\
\mathrm{NS}\end{array}$ & $\begin{array}{l}\chi^{2}=4 \cdot 1 \\
\mathrm{df}=1\end{array}$ & $\mathrm{p}<0.05$ \\
\hline
\end{tabular}

although the acetylated SP also makes some contribution. Corresponding to this, the side effects were more prone to occur among the slow acetylators.

It may be noted that serum levels of acetylated SP were on average higher in the patients with symptomatic side effects than in those without side effects. At first sight this may appear to be unexpected since acetylated SP is more readily produced by fast acetylators, who are much less prone to symptomatic side effects than slow acetylators. The apparent anomaly is easily explained because there is considerable inter-individual variation in the circulating levels of total SP when subjects are on the same dose of SASP. The acetylator status has some influence on this but not sufficient in itself to account for the differences between persons and this is evident from the SDs given in tables 1 and 4 . As a result, because the dose related side effects are strongly correlated with the circulating levels of total SP, some of the patients with such side effects are fast acetylators, and therefore the net effect is that all the metabolites of SP tend to be higher in the group of patients with these side effects.

Further information emerges from studying the individual side effects in relation to serum concentrations and acetylator phenotype. Table 5 shows that the common side effects, namely nausea, malaise, and headache, were almost always confined to the slow acetylators and were associated with high circulating levels of SP, both free and total.
In addition to registering these symptomatic side effects, all the patients were monitored for haematological side effects by full blood counts, reticulocyte counts, red cell indices, morphology of the erythrocytes, intravital staining for Heinz bodies, methaemoglobin, and direct Coombs's test. No patient developed a frank haemolytic anaemia or evidence of marrow depression, both of which are known hazards of SASP therapy, but an appreciable number developed minor haematological abnormalities. These abnormalities were dose related and, with the exception of methaemoglobinaemia, they were most likely to occur in the patients with high

TABLE 6 Haematological abnormalities and their relation to the acetylator phenotypes in the patients in 2 and $4 \mathrm{~g}$ dosage groups.

\begin{tabular}{|c|c|c|c|}
\hline \multirow{2}{*}{$\begin{array}{l}\text { Haematological } \\
\text { abnormality }\end{array}$} & \multicolumn{2}{|c|}{ Acetylator phenotype } & \multirow{2}{*}{$\begin{array}{l}\text { Significance of } \\
\text { difference }\end{array}$} \\
\hline & $\begin{array}{l}\text { Fast } \\
(n=44)\end{array}$ & $\begin{array}{l}\text { Slow } \\
(n=68)\end{array}$ & \\
\hline Crenated RBC & 14 & 49 & $\chi^{2}=17.6, p<0.001$ \\
\hline Methaemoglobinaemia & & & \\
\hline $\begin{array}{c}(>1 \cdot 5 \%) \\
\text { Macrocytosis }\end{array}$ & 24 & 29 & $\chi^{2}=1 \cdot 5, p>0.2$ \\
\hline$(\mathrm{MCV}>100 \mathrm{fl})$ & 4 & 13 & $\begin{array}{l}\chi^{2}(\text { with Yates's } \\
\quad \text { correction })=1.4 \\
\mathrm{p}>0.2\end{array}$ \\
\hline Heinz bodies & 0 & 8 & $\begin{array}{l}\chi^{2} \text { (with Yates's } \\
\quad \text { correction })=3.9 \\
p>0.05\end{array}$ \\
\hline $\begin{array}{l}\text { Reticulocytosis } \\
\quad(>2 \%)\end{array}$ & 0 & 7 & $\begin{array}{l}\chi^{2}(\text { with Yates's } \\
\text { correction })=3 \cdot 2, \\
0 \cdot 1>p>0.05\end{array}$ \\
\hline
\end{tabular}

TABLE 5 Symptomatic side effects in the patients ingesting $4 \mathrm{~g} S A S P$ daily and their relation to the serum concentration of SASP and its metabolites and to the acetylator status. Among the 56 patients on this dose of SASP, 21 experienced one or more of these side effects.

\begin{tabular}{|c|c|c|c|c|c|c|c|}
\hline \multirow[t]{2}{*}{ Side effects } & \multirow[t]{2}{*}{ No } & \multicolumn{4}{|c|}{ Serum concentrations $(\mu g / m l)($ mean $\pm S D)$} & \multicolumn{2}{|c|}{ Acetylator status } \\
\hline & & $S A S P$ & Free $S P$ & Total $S P$ & Total 5-ASA & Fast & Slow \\
\hline Nausea & 11 & $22 \cdot 8 \pm 11 \cdot 3$ & $44 \cdot 8 \pm 8 \cdot 2$ & $69 \cdot 5 \pm 9 \cdot 7$ & $1 \cdot 6 \pm 0 \cdot 5$ & 1 & 10 \\
\hline Malaise & 5 & $29 \cdot 4 \pm 19 \cdot 9$ & $45.5 \pm 8.9$ & $68 \cdot 0 \pm 13 \cdot 8$ & $1.8 \pm 0.5$ & 0 & 5 \\
\hline Headache & 4 & $9 \cdot 0 \pm 3 \cdot 4$ & $48 \cdot 1 \pm 18 \cdot 4$ & $67 \cdot 2 \pm 19 \cdot 4$ & $3 \cdot 1 \pm 2 \cdot 7$ & 0 & 4 \\
\hline Myalgia & 2 & $36 \cdot 5$ & $49 \cdot 7$ & $76 \cdot 9$ & $1 \cdot 1$ & 0 & 2 \\
\hline Diarrhoea & 2 & $17 \cdot 5$ & $28 \cdot 9$ & $59 \cdot 0$ & $1 \cdot 8$ & 1 & 1 \\
\hline Anal soreness & 2 & $10 \cdot 6$ & $30 \cdot 0$ & $53 \cdot 4$ & $2 \cdot 0$ & 1 & 1 \\
\hline Anal mucus discharge & 1 & $33 \cdot 2$ & $50 \cdot 1$ & $62 \cdot 6$ & $1 \cdot 9$ & 0 & 1 \\
\hline Flatulence & 2 & $20 \cdot 8$ & $62 \cdot 1$ & $75 \cdot 0$ & $3 \cdot 1$ & 1 & 1 \\
\hline Dysuria & 3 & $17 \cdot 1$ & $39 \cdot 6$ & $67 \cdot 0$ & $1 \cdot 9$ & 1 & 2 \\
\hline Anorexia & 2 & $15 \cdot 1$ & $33 \cdot 0$ & $53 \cdot 2$ & $1 \cdot 9$ & 0 & 2 \\
\hline Indigestion & 1 & $13 \cdot 7$ & $44 \cdot 5$ & $64 \cdot 2$ & $2 \cdot 0$ & 0 & 1 \\
\hline Insomnia & 1 & $21 \cdot 0$ & $41 \cdot 1$ & $67 \cdot 8$ & $2 \cdot 8$ & 0 & 1 \\
\hline Dizziness & 2 & $12 \cdot 5$ & $26 \cdot 2$ & $47 \cdot 6$ & $1 \cdot 0$ & 1 & 1 \\
\hline
\end{tabular}


TABLE 8 Serum concentrations of SASP and of SP and its metabolites $(\mu \mathrm{g} / \mathrm{ml}, \mathrm{mean}+\mathrm{SD})$ at the beginning of the study, after dummy tablets, and after oral prednisolone, and the results of paired t test between the serum concentrations after dummy tablets and those after oral prednisolone.

\begin{tabular}{|c|c|c|c|c|c|c|}
\hline & $S A S P$ & Total $S P$ & Free $S P$ & $A C-S P$ & $S P-G l u c$ & $A C-S P-G l u c$ \\
\hline At the beginning & $10 \cdot 2 \div 6 \cdot 2$ & $25 \cdot 6 \pm 9 \cdot 3$ & $14 \cdot 3 \pm 8 \cdot 7$ & $7 \cdot 2 \div 3 \cdot 7$ & $0 \cdot 9 \pm 0 \cdot 7$ & $3 \cdot 2 \pm 1 \cdot 9$ \\
\hline After dummy tablets & $10 \cdot 2 \pm 7 \cdot 8$ & $27 \cdot 8 \pm 1 \cdot 0$ & $15 \cdot 8 \pm 9 \cdot 3$ & $8 \cdot 4 \pm 3 \cdot 7$ & $1 \cdot 0 \pm 0 \cdot 9$ & $3 \cdot 1 \pm 1 \cdot 8$ \\
\hline After prednisolone tablets & $10 \cdot 2 \pm 7 \cdot 2$ & $27 \cdot 1 \pm 1 \cdot 0$ & $14 \cdot 8 \pm 9 \cdot 4$ & $8 \cdot 2 \pm 3 \cdot 0$ & $1 \cdot 0 \pm 0 \cdot 9$ & $3 \cdot 8 \div 1 \cdot 9$ \\
\hline $\begin{array}{l}\text { Results of paired } t \text { test } \\
\text { between the serum } \\
\text { concentrations after dummy } \\
\text { tablets and those after } \\
\text { prednisolone tablets }\end{array}$ & $\begin{array}{ll}t & 1 \cdot 3 \\
\mathrm{p} & \mathrm{NS}\end{array}$ & $\begin{array}{l}1 \cdot 0 \\
\text { NS }\end{array}$ & $\begin{array}{l}1 \cdot 5 \\
\mathrm{NS}\end{array}$ & $\begin{array}{l}0 \cdot 3 \\
\text { NS }\end{array}$ & $\begin{array}{l}0.2 \\
\text { NS }\end{array}$ & $\begin{array}{l}0.9 \\
\text { NS }\end{array}$ \\
\hline
\end{tabular}

serum concentrations of SP and hence were chiefly found in the slow acetylators (table 6). Further analysis of the data shows that these haematological side effects are correlated with free SP and total SP, an effect which is especially evident in the $4 \mathrm{~g}$ daily dosage group (table 7). Although methaemoglobinaemia was dose related, it showed no association with the serum concentration of total SP. The only association to emerge was that, with the $4 \mathrm{~g}$ daily dosage, there was a relationship between acetylated SP and the liability to develop methaemoglobinaemia. This should imply that methaemoglobinaemia is more like to occur in fast rather than slow acetylators and this was indeed the case in this dosage group which consisted of 21 fast and 35 slow acetylators $\left(\chi^{2}=5 \cdot 2, \mathrm{df}=1, \mathrm{p}<0 \cdot 05\right)$.

The haematological side effects were unrelated to the circulating levels of SASP. There was some association with the serum concentration of 5-ASA but the actual concentrations were so low that we think that this association is of no practical significance and merely reflects the fact that the circulating level of 5-ASA usually runs in parallel with that of $\mathrm{SP}$, although at a much lower level.

INFLUENCE OF PREDNISOLONE ON THE METABOLISM OF SASP

Table 8 shows the serum concentrations of SASP and its metabolites in the 36 patients with ulcerative colitis in remission who volunteered to take prednisolone for one week and dummy tablets for one week, the order being randomised. The serum concentrations of SASP and of SP and its metabolites were unaffected by the trial tablets, whether prednisolone or dummy. 5-ASA was not measured as it is usual for its serum concentration to be very low when SASP is being used in a dose of $2 \mathrm{~g}$ daily.

Although the serum concentrations were virtually unaffected, prednisolone brought about a slight but statistically significant increase in percentage acetylation when compared with the value at the start of the experiment or with that found after one week on dummy tablets. For example, when compared with dummy tablets, Student's paired $t$ test gave $t=3 \cdot 1$, $p=<0 \cdot 01$. This small increase in percentage acetylation was uniformly distributed among fast and slow acetylators, and its effect was much too small to change the acetylator status of any subject. Prednisolone had no appreciable effect upon the hydroxylation.

\section{Discussion}

The present studies have confirmed in a large series of patients the findings of Schröder and Evans $^{8}$ and Das et $a l^{5}$ that the side effects of SASP are closely related to the serum concentration of SP and that this in turn is influenced by the acetylator phenotype. For any given dose of SASP the concentrations of both free SP and total SP are on average higher in the slow acetylators, but there is an overlap with the serum levels of the fast acetylators. The bigger the dose of SASP, the greater the difference between the fast and the slow acetylators. The probable explanation is that acetylated forms of SP are more readily excreted by the kidney than is free SP, ${ }^{314}$ with the result that the bigger doses of SASP cause the slow acetylators to have increasing difficulty in excreting the SP.

As far as the symptomatic side effects of SASP are concerned, the present study adds weight to the view that the common side effects (nausea, general malaise, and headache) occur in patients with high circulating levels of SP and hence are specially likely to occur in slow acetylators. These same symptoms are common side effects of sulphonamide therapy. ${ }^{715}$ In the series of patients now presented, nausea, general malaise, and headache were virtually confined to the slow acetylators. The other side effects were individually not sufficiently common to allow any conclusion about their possible relationship to the acetylator phenotype.

There are also haematological side effects which may be asymptomatic but which can be detected by 
appropriate monitoring. In the present series, poikilocytosis, macrocytosis, reticulocytosis, and the presence of Heinz bodies were dose related and were associated with high circulating levels of free SP and total SP, particularly when the larger doses of SASP were being administered. Methaemoglobinaemia was also dose related but it was associated with high circulating levels of acetylated SP and hence was significantly more common among the fast acetylators, the only complication to show this association.

Prednisolone has been found not to alter the metabolism of SASP materially except in one respect, namely that it slightly increases the degree of acetylation. This change, although statistically significant, is not sufficiently pronounced to alter the serum concentrations of SP and its metabolites to any appreciable degree. It is also too slight to affect the acetylator status. The reason for the increased acetylation is not certain. The two main possibilities are that prednisolone modifies the renal excretion of free SP and acetylated SP or that it enhances the process of acetylation by enzyme induction. Detailed urinary studies were not practicable in the present study as it was performed on out-patients, so we are unable to say which of these two possibilities is the more likely.

Prednisolone had no appreciable effect upon hydroxylation. Hydroxylation was found to be unimodally distributed and highly variable, the percentage hydroxylation ranging from 1 to $75 \%$ in the 185 patients in whom it was studied. Moreover, the degree of hydroxylation varied markedly from time to time in the same patient, whereas the percentage acetylation was found to be reasonably constant in any given patient. The degree of hydroxylation bore no relationship to acetylation status. We found no evidence in this large series to support the possibility suggested by Schröder and Evans ${ }^{8}$ that subjects might be found who were slow acetylators and very slow hydroxylators and who would therefore develop exceptionally high serum concentrations of SP with a given dose of SASP. In effect, the degree of hydroxylation is a variable characteristic and it is impossible to speak of fast and slow hydroxylators.

As far as the acetylator phenotype is concerned, the patients with ulcerative colitis have been found to have similar proportions of fast and slow acetylators as Evans ${ }^{7}$ found for the normal British population. From a genetic viewpoint, it is evident that the acetylator phenotype has no bearing on the liability to develop ulcerative colitis, a negative point worth making, as there is abundant evidence that ulcerative colitis occurs in first degree relatives much more often than would be expected by chance. ${ }^{16}$

\section{References}

1 Misiewicz J, Lennard-Jones JE, Connell AM, Baron JHs Jones FA. Controlled trial of sulphasalazine in maintenance therapy for ulcerative colitis. Lancet $1965 ; \mathbf{i}: 185-8$.

2 Dissanayake AS, Truelove SC. A controlled therapeutic trial of long-term maintenance treatment of ulcerative colitis with sulphasalazine (Salazopyrin). Gut 1973;14: 923-6.

${ }^{3}$ Schröder H, Campbell DES. Absorption, metabolism and excretion of salicylazosulfapyridine in man. Clin Pharmacol Ther 1972;13:539-51.

4 Peppercorn MA, Goldman P. Distribution studies of salicylazosulfapyridine in man. Clin Pharmacol Ther 1972; 13:539-51.

5 Das KM, Eastwood MA, McManus JPA, Sircus W. The metabolism of salicylazosulphapyridine in ulcerative colitis. I. The relationship between metabolites and the response to treatment in inpatients. II. The relationship between metabolites and the progress of the disease studied in outpatients. Gut $1973 ; 14: 631-41$.

6 Azad Khan AK, Aronson JK, Truelove SC. The disposition and metabolism of sulphasalazine (salicylazosulphapyridine) in man. Br J Clin Pharmacol 1982;13: 523-8.

7 Evans DAP. An improved and simplified method of detecting the acetylator phenotype. J Med Genet 1969; 6:405-7.

${ }^{8}$ Schröder H, Evans DAP. Acetylator phenotype and adverse effects of sulphasalazine in healthy subjects. Gut 1972;13:278-84.

9 Azad Khan AK, Truelove SC. Circulating levels of sulphasalazine and its metabolites and their relation to the clinical efficacy of the drug in ulcerative colitis. Gut 1980;21:706-10.

10 Azad Khan AK, Howes DT, Piris J, Truelove SC. The optimum dose of sulphasalazine for maintenance treatment in ulcerative colitis. Gut 1980;21:232-40.

11 Hansson KA. Determination of free and acetylated 5 -aminosalicylic acid in serum and urine after administration of salicylazosulphapyridine. Acta Pharm Suec $1973 ; 10: 153-5$.

12 Hansson KA. Sandberg M. Determination of sulphapyridine and its metabolites in biological materials after administration of salicylazosulphapyridine. Acta Pharm Suec 1973;10:87-92.

13 Sandberg M, Hansson KA. Determination of salicylazosulphapyridine in biological materials. Acta Pharm Suec 1973;10:107-10.

14 Dost FH. Grundlagen der Pharmakokinetik. 2nd ed. Stuttgart: Thieme, 1968:298-312.

15 Hawking F, Lawrence JS. The sulphonamides. London: Lewis, 1950.

16 Mendeloff AL. The epidemiology of idiopathic inflammatory bowel disease. In: Kirsner JB, Shorter RG, eds. Inflammatory bowel disease. Philadelphia: Lea and Febiger, 1975:3-19.

Requests for reprints to Dr S C Truelove, Gastroenterology Unit, The Radcliffe Infirmary, Oxford OX2 6HE.

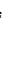

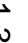

